\title{
Melanoma-Associated Antigen 3
}

National Cancer Institute

\section{Source}

National Cancer Institute. Melanoma-Associated Antigen 3. NCI Thesaurus. Code

C17513.

Melanoma-associated antigen $3(314 \mathrm{aa}, \sim 35 \mathrm{kDa}$ ) is encoded by the human MAGEA3 gene. This protein may be involved in embryological development. 